\title{
Psi Chi in Global World: Vision of 9 International Chapters
}

\author{
Harold Takooshian ${ }^{1}$, Yarielizmar Nieves-Lebrón ${ }^{2}$, Bernadette M. Delgado-Acosta ${ }^{2}$, \\ Daniela Talavera Pagán ${ }^{3}$, Nelson D. Cruz-Bermúdez ${ }^{3}$, Andrew M. Rivers ${ }^{4}$, \\ María del Pilar Grazioso ${ }^{5}$, Marinés Mejía ${ }^{5}$, Diana Williams ${ }^{6}$, Grace Sooknanan ${ }^{6}$, \\ Alicia Hosein ${ }^{6}$, Valeriia S. Tarkhova ${ }^{7}$, Sayad Z. Kardashova ${ }^{8}$, Yuliya V. Kozhukhova ${ }^{8}$, \\ Tsee Leng Choy ${ }^{9}$, Kyle Danielson ${ }^{10}$, Marios Adonis ${ }^{11}$, \\ Yianna Ioannou ${ }^{11}$, Ester Lima ${ }^{11}$ \\ ${ }^{1}$ Fordham University \\ 113 W. 60th St., New York, NY 10023, United States of America \\ ${ }^{2}$ University of Puerto Rico at Mayagüez \\ PO Box 9000, Mayagüez, 00681-9000, Puerto Rico \\ ${ }^{3}$ University of Puerto Rico at Río Piedras \\ 9 Ave. Universidad, Suite 901, San Juan, 00925, Puerto Rico \\ ${ }^{4}$ University of British Columbia \\ 2136 West Mall, Vancouver, BC V6T 1Z4, Canada \\ ${ }^{5}$ University of the Valley of Guatemala \\ 18 Ave., 11-95 Zona 15, Vista Hermosa III, Guatemala 01015, Guatemala \\ ${ }^{6}$ University of the West Indies \\ St. Augustine Campus, Trinidad and Tobago, West Indies \\ ${ }^{7}$ National Research University "Higher School of Economics" \\ 20 Myasnitskaya St., Moscow, 101000, Russian Federation \\ ${ }^{8}$ Peoples' Friendship University of Russia (RUDN University) \\ 6 Miklukho-Maklaya St., Moscow, 117198, Russian Federation \\ ${ }^{9}$ HELP University \\ Jalan Sri Semantan 1, Off Jalan Semantan, Bukit Damansara, 50490, Kuala Lumpur, Malaysia \\ ${ }^{10}$ University of Toronto Scarborough \\ 1265 Military Trail, Toronto ON M1C 1A4, Canada \\ ${ }^{11}$ University of Nicosia \\ 46 Makedonitissas Ave., Nicosia, CY-241, Cyprus
}

\begin{abstract}
Since 2009, when Psi Chi became the International Honor Society in Psychology, outstanding faculty and students across many nations have stepped forward to join the Psi Chi family of 750000 life members in 1130 schools on six continents. How is the Psi Chi experience changing lives around the world, as it has been doing since 1929 in the USA? Here, for the first time, Psi Chi "pioneers" in 9 international Chapters share in their own words and images their Psi Chi experiences.
\end{abstract}

Key words: Psi Chi; International Honor Society in Psychology; international psychology; international students; cross-national cooperation

(C) Takooshian H., Nieves-Lebrón Ya., Delgado-Acosta B.M., Talavera Pagán D., Cruz-Bermúdez N.D., Rivers A.M., del Pilar Grazioso M., Mejía M., Williams D., Sooknanan G., Hosein A., Tarkhova V.S., Kardashova S.Z., Kozhukhova Yu.V., Tsee Leng Choy, Danielson K., Adonis M., Ioannou Y., Lima E., 2019

This work is licensed under a Creative Commons Attribution 4.0 International License 


\section{Introduction}

(by Harold Takooshian)

In March 2019, as a Past-President of Psi Chi and RUDN Journal of Psychology and Pedagogics editorial board member, I appealed to representatives of 20 international Psi Chi Chapters with an invitation to complete a survey dedicated to the 10th anniversary of Psi Chi internationalization. The survey included the following items:

1) Your school? 3 sentences - year, location, size, features?

2) Psi Chi installation? Installation date, why your school?

3) Founding chapter Faculty Advisor(s) and President(s)?

4) Impact so far? Psi Chi activities? Any past highlights? Other impacts?

5) Future possibilities? Interaction with other Chapters? International opportunities?

6) Wishes? (Anonymous.) Anythings you wish Psi Chi offered?

7) A photo or two: Installation? Conference? Other activity?

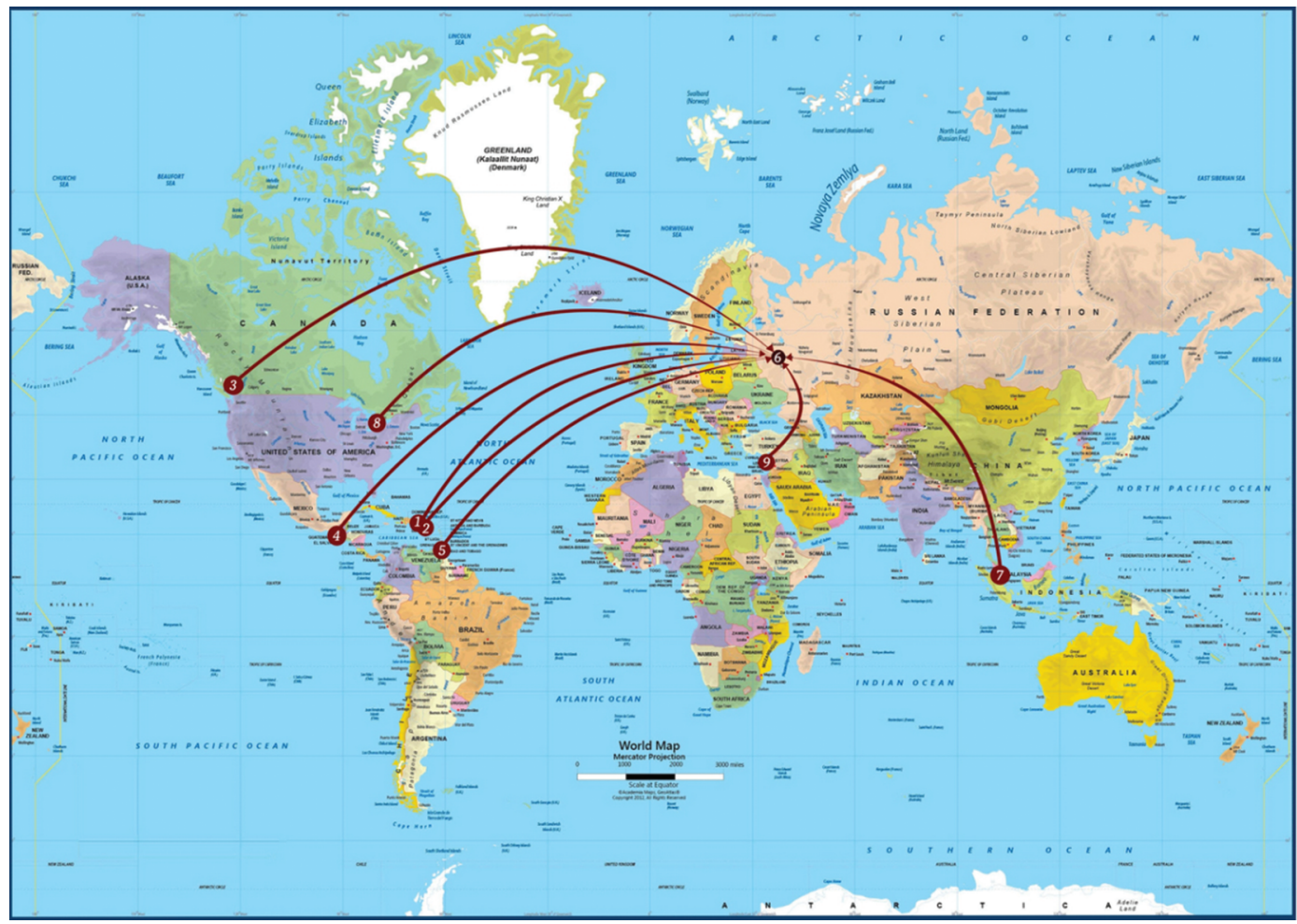

Figure 1. World map ${ }^{1}$ with 9 international Psi Chi Chapters that presented their reports:

1 - University of Puerto Rico of Mayagüez (Puerto Rico); 2 - University of Puerto Rico at Río Piedras (Puerto Rico); 3 - University of British Columbia (Canada); 4 - University of the Valley of Guatemala (Guatemala); 5 - University of the West Indies (Trinidad and Tobago); 6 - Peoples Friendship University of Russia (RUDN University) (Russia); 7-HELP University (Malaysia); 8 - University of Toronto Scarborough (Canada); 9 - University of Nicosia (Cyprus)

During the month RUDN Journal of Psychology and Pedagogics editorial board received completed surveys from 9 Chapters representing 7 countries of the world (Figure 1). This article joins the reports of these Chapters, which are presented below in the order of their

${ }^{1}$ Map source: https://video-photo.net/karty/karta-mira. Figure design by Evelina Simanskaya (RUDN University student). 
origin: from very first Psi Chi international Chapter at the University of Puerto Rico, Mayagüez Campus to one of the newest ones at the University of Nicosia, Cyprus. The final part of the article contains wishes that are arranged in a random order.

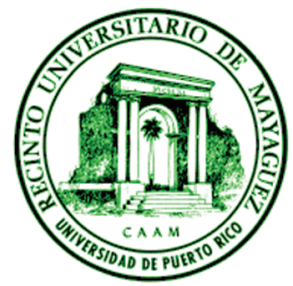

\section{Psi Chi at University of Puerto Rico, Mayagüez Campus}

(by Yarielizmar Nieves-Lebrón \& Bernadette M. Delgado, Ph.D.)

1. The University of Puerto Rico, Mayagüez Campus, UPR-M (https://www.uprm. edu/portada/) is located in the town of Mayagüez, Puerto Rico. It is the second largest campus of the UPR system and the only one with a School of Agriculture and a graduate program in Marine Sciences in Puerto Rico. Established on September 23, 1911, the campus has four academic units: The Colleges of Agricultural Sciences, Engineering, Arts and Sciences, and Business Administration. Currently, the staff includes over 800 professors and researchers, 264 agricultural extension workers and 12264 students enrolled in the various undergraduate and graduate programs. It also has a renowned Graduate Program that offers masters and doctorates. In addition, this campus has more than 100 student organizations and annual events such as Five Days with Our Earth (event to highlight agriculture), Interuniversity Fair of the LAI (athletic competitions among the universities of Puerto Rico), International dinner (dinner shared with typical dishes of Puerto Rico and international) and the ignition of Christmas (party of the beginning of the Christmas season in the Campus). The University of Puerto, Mayagüez Campus is a founding member of the LAI (Interuniversity Athletic League). It is the only university that participates in all sports sponsored by the LAI. The UPR-M currently participates in 16 men's sports and 12 women's sports, with a total of 373 athletes. The vision of this university is to be a vanguard institution in higher education and research, transforming society through the search for knowledge, in an environment of ethics, justice, and peace.

2. Psi Chi UPR-M is the first Chapter established in Puerto Rico and has been active since 2008. It was founded by the student Zaade A. Torres and Dr. Bernadette Delgado has been the Faculty Advisor since then. The board of directors, for the year 2018-2019, is composed by Alondra Nieves (President), Claudia A. Mercado (Vice President), Gabriela N. Torres (Secretary), Sheila E. Chaparro-Pérez (Treasurer), Yarielizmar NievesLebrón (Historian), Ivan J. Feliciano-Romeu (Public Relations Officer), Andrea Velez (Webmaster) and William J. Cartagena-Nieves (Event Coordinator) (Figure 2). We are characterized by unity, leadership, and responsibility. Psi Chi has allowed us to expand our knowledge and skills through social work, workshops, conferences, and fraternization.

3. The founding and current Faculty Advisor is Dr. Bernadette Delgado and the first President was Zaade A. Torres. The President for the year 2018-2019 is Alondra Nieves. 


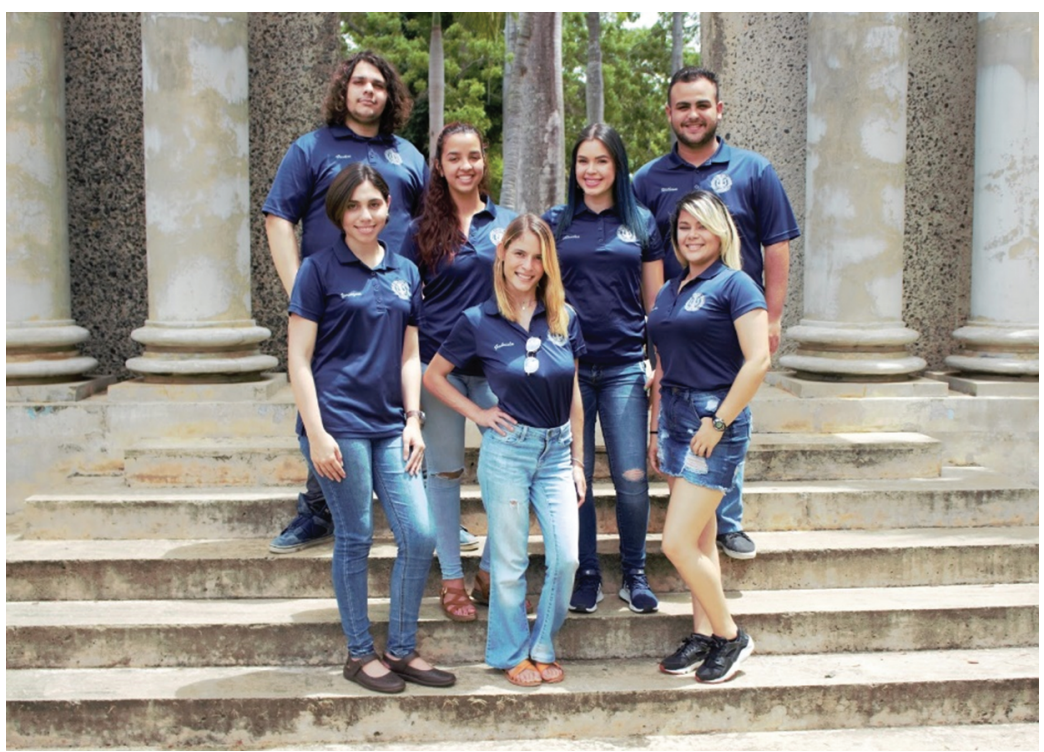

Figure 2. Current Board of Directors of UPR-M Psi Chi Chapter

4. In our chapter, we conceive community service as an integral part of the activities to be accomplished. The purpose is for members to have an experience beyond the academic realm and apply what they have learned to a real-world context. To accomplish this objective, we carried out several community service activities.

A. One of them was a full breakfast prepared for the homeless. For this, we joined forces with the Student Association for Community Support (AEAC), since they had access to the people in need. We were responsible for preparing everything necessary for the breakfast, it was accomplished with donations from our members. It was an unforgettable moment for us; not only did we provided a meal for them, but we also interacted with them, played dominoes, and listened to the stories they told us. The most rewarding thing about this experience is to know that you can achieve anything with the tools that the society of honor and the profession itself offers you.

B. The International Honor Society in Psychology is distinguished by the unique training it offers to its members. For this reason, we had a wide variety of workshops and conferences intended to provide knowledge of how to progress in this profession. We provided conferences about options for graduate schools in Puerto Rico, how to apply and participate in internships and the preparation of a curriculum vitae. Also, a conference dedicated to the different areas of psychology such as the psychology of nutrition, organizational psychology, social psychology, and so on. We also had different workshops such as "True Colors" (workshop dedicated to knowing their personality), first aid (CPR), personal defense and others. Thanks to these activities we can expand our knowledge beyond our academic curriculum and improve ourselves to help others.

C. This Chapter is also characterized for being very friendly, so much that we consider ourselves family. Fundraising sales for the induction ceremony became extremely fun and dynamic. The people around us enjoy the interaction of us and how we handle different conflicts. We are characterized by empathy, kindness, affection, responsibility, punctuality, and happiness. We want people to feel appreciated and welcomed. As the 
director board we always make it our mission to get to know everyone since they are the essence of Psi Chi.

D. The induction ceremony for the current year took place on May 7, 2019 (Figure 3). We are proud to have inducted 32 new members. In addition, following the protocol already established by Psi Chi Central, we establish the new board of directors composed by Paulina D. Marrero-Torres (President), Arnaldo L. Lopez-Cruz (Vice President), Glorianis Valentín-Morell (Secretary), Yomarie Vargas-Morales (Treasurer), Bryan Garcia-Muñiz (Historian), Andrea Colón-Gonzalez (Public Relations Officer), Maryliz Soto-Quiles (Webmaster) and Elizabeth Montalvo-Ruiz (Event Coordinator) (Figure 4).

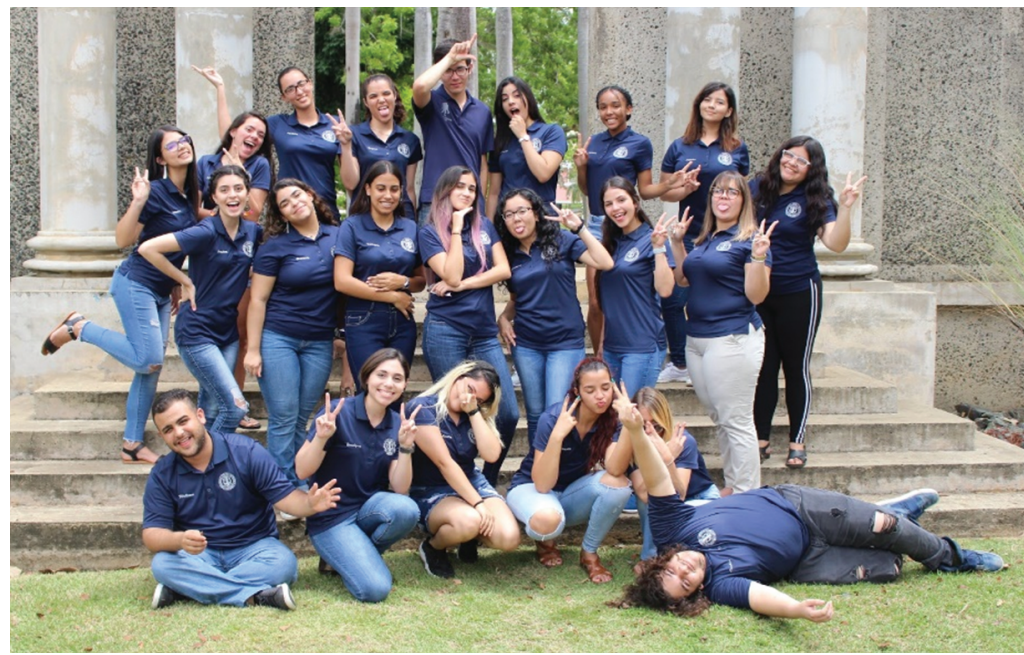

Figure 3. New members of UPR-M Psi Chi Chapter

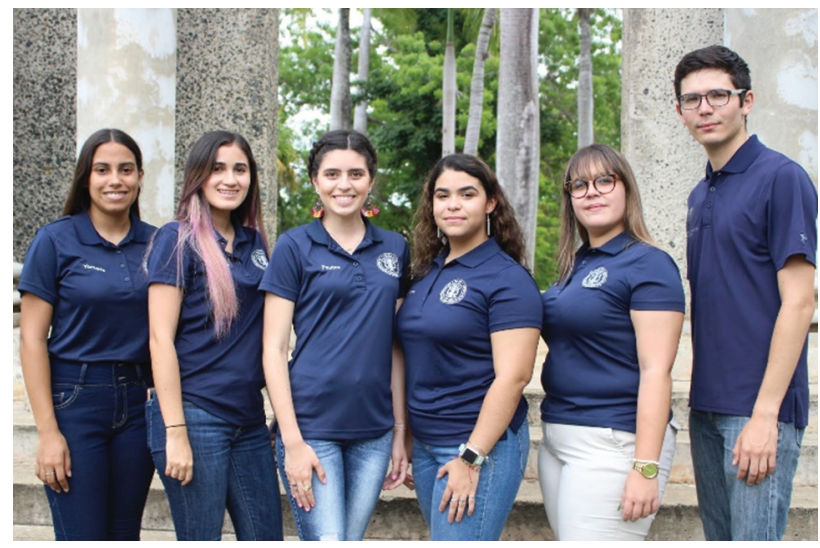

Figure 4. New Board of directors of UPR-M Psi Chi Chapter

We recognize the excellent work of our mentor Dr. Bernadette Delgado who has guided and shaped us into what we are today, not only as part of the society but also as our professor and academic counselor. Psi Chi is much more than we could imagine. It has given us a family for life and has provided us with the knowledge and skills necessary to become better professionals today and tomorrow. 


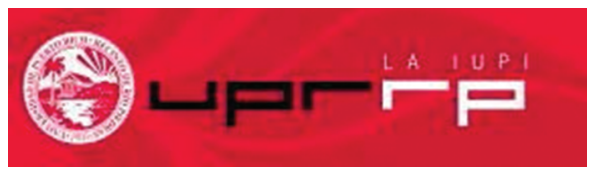

\section{Psi Chi at University of Puerto Rico, Río Piedras Campus, Puerto Rico} (by Daniela Talavera Pagán \& Nelson D. Cruz-Bermúdez, Ph.D.)

1. The University of Puerto Rico at Río Piedras (UPR-RP) located in the town of San Juan, Puerto Rico, is the oldest and largest campus within the UPR system. Established in 1903, the UPR-RP provides higher education every year to over 18000 students from all over the country. It offers 70 undergraduate-level degrees and 19 graduate-level degrees, with 71 areas of specializations. The mission of the UPR-RP and its deanships and schools together is to foster an integrated education, promote intellectual curiosity and critical thinking, and embrace ethics, aesthetic values, social awareness and responsibility among students, faculty and alumni (http://www.uprrp.edu/).

2. In 2009, the Psychology Department faculty at UPR-RP, specifically professors Guillermo Bernal and Dolores Miranda, and student Jhenny Zhen, presented a proposal to activate a Psi Chi Chapter at our campus. In August 2010, our Chapter was officially approved and celebrated the first members' installation ceremony on March $4^{\text {th }}, 2011$.

3. The founding Chapter advisor was Professor Guillermo Bernal and first president was Nicole Ryan-Nolla. Dr. Cruz-Bermúdez became the Advisor in 2017 and the Chapter's current President is Ms. Daniela Talavera-Pagán. Since 2011, the Chapter has offered dozens of activities, and posts its reports and photos on social media (http:// psichiuprrp.weebly.com/; https://www.facebook.com/psichiuprrp/; https://www. instagram.com/psichi_uprrp/).

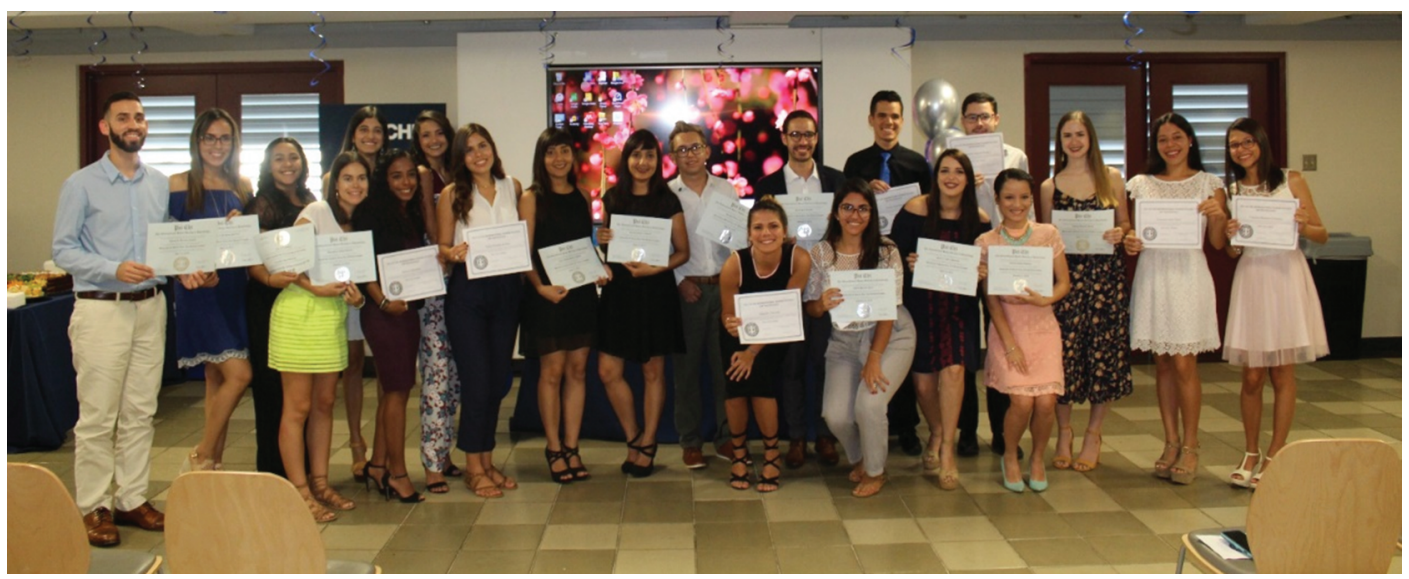

Figure 5. Introduction ceremony at UPR-RP Psi Chi Chapter, 2018

4. In the spring of 2019, our Psi Chi Chapter celebrated its $9^{\text {th }}$ anniversary. The 2018-2019 Chapter directorate designed several activities with three particulars goals in mind.

A. It is important to offer opportunities that positively contribute to members' professional development. Because of this, on Sep. 19, 2018, we offered the seminar Road to graduate 
school, in which Professor Cruz-Bermúdez presented tips to prepare successful graduate school applications. Also, on Dec. 5, 2019, we offered a mini symposium Sub-Disciplines within Psychology, in which academicians from different psychology areas (e.g., clinical, social, industrial, school) exposed particulars about their scopes. Lastly, on Feb. 27, 2019, we provided the Curriculum Vitae Workshop, through which Dr. Karinette Rivera provided useful details on how to create and keep a professional, updated CV.

B. In our Chapter, we strive to create mental health-related educational workshops and activities. Social Community Psychology Professor, Dr. Yovanka Bultrón, provided two essential activities for our members: Microaggression Workshop (Oct. 1, 2018), as well as Psychological First Aid Training focusing on panic and anxiety attacks. President Daniela Talavera is one of the three organizers of the first Mental Health Festival that will be held on April, 2019. This activity, first of its kind in the history of the UPR-RP will be open for the community and we expect to have over 30 mental health related entities to provide information about their services, along with ongoing workshops during the day. Other activities already confirmed for the semester are: Mental Health and the LGBTTIQ+ Community Workshop, by Dr. Teresa Gracia, Sexual Aggression Workshop by the ERAAS Program, Clinical Psychology Workshop by Dr. Amaryllis Muñoz and Methods of Relaxation Training by Dr. Yovanka Bultrón.

C. We also value to contribute to society through volunteer work. Last semester, we participated in two activities that involved donating toys for underprivileged children in Puerto Rico as well as around the world. In the Build a Box activity, members decorated a shoebox and filled it with toys that were later sent to an organization that distributes those boxes around the world. The other activity was gathering donated toys and clothing for an underprivileged community in Puerto Rico.

5. For the future, the Psi Chi Chapter at UPR-RP would love to collaborate to implement an international student exchange program as well as a research symposium, where students from multiple Chapters all over the world have an opportunity to present their research and interchange ideas.

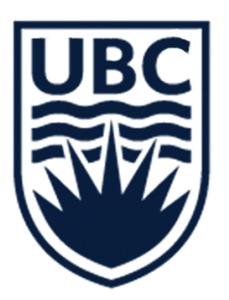

\section{Psi Chi at the University of British Columbia (UBC), Canada}

(by Andrew M. Rivers, Ph.D.)

1. The Psi Chi Chapter at the University of British Columbia (UBC) is located in Vancouver, Canada. The University of British Columbia is one of the top universities in Canada. The psychology programme specifically, consistently ranks among the top 10 programs and, for 2018 and 2019, was ranked as the topmost university for psychology studies by Macleans (https://www.macleans.ca/schools/university-of-british-columbia/). 
2. The Psi Chi Chapter was started on November 23, 2011, as the second existing Psi Chi affiliated program in the country (after the nearby Chapter at University of Victoria) (https://psichi.psych.ubc.ca/; https://www.facebook.com/psichiUBC/). To date, our Chapter has inducted more than 500 members.

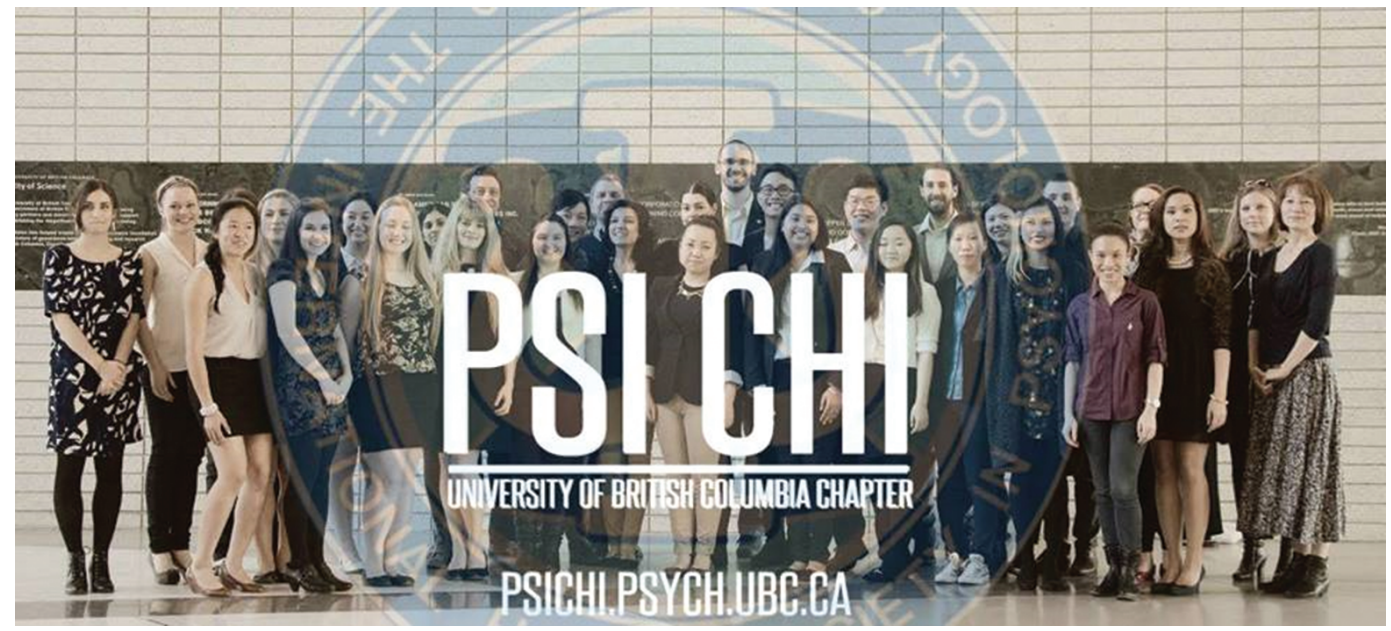

Figure 6. 2016 UBC Psi Chi Inductees

3. The founding chapter Faculty Advisor was Professor Michael Souza and first President was Kaitlyn Goldsmith.

4. The UBC Chapter of Psi Chi has sought to support the scientific development of its members. To this end, our Chapter has established four different research awards. Across all of these awards, UBC Psi Chi has awarded more than $\$ 12000$ in funds to support student research. Prior to a department-wide Psychology Undergraduate Research Conference (PURC), Psi Chi organizes a practice session where students can rehearse their presentations for their conference talks and poster discussions. Outside UBC Psi Chi's support for student research, the Chapter also organizes a yearly trip for high school (secondary) students in the greater Vancouver area to visit the Psychology Department. This year, 50 high school students attended for an evening discussion of the undergraduate psychology programme at UBC and were able to tour four active psychology research labs.

5. Psi Chi at UBC is now developing events to support student employment following their undergraduate studies. To this end, the UBC Psi Chi Chapter is organizing our first careers event for psychology majors. At this event, students will have the opportunity to hear from and network with local businesses and organizations that hire students who have graduated with a psychology degree. 


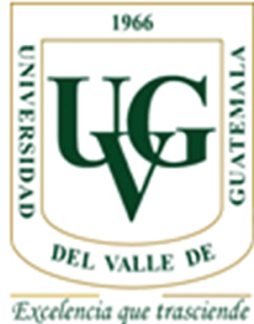

\section{Psi Chi at University of the Valley of Guatemala (UVG), Guatemala}

(by María del Pilar Grazioso, Ph.D. \& Marinés Mejía)

1. The University of the Valley of Guatemala (UVG) is located in Guatemala City (http://uvg.edu.gt). It was formed in 1966 due to the need of promoting the learning of pure sciences. Its focus has evolved through time and now it is one of the top leading universities focused on science and technology. The mission of the university is to develop change agents that are capable of creating an impact in society through their educational experiences and research based in science and technology. UVG has seven core values: ethics, academic excellence, responsibility, respect, critical thinking, compromise and innovation and entrepreneurship. It has two external campuses: University of the Valley of Guatemala South Campus located in Santa Lucía Cotzumalguapa, Escuintla and Altiplano Campus of University of the Valley in Sololá (http://www.campussur.uvg.edu. gt/; http://altiplano.uvg.edu.gt/). These campuses offer relevant academic and extension programs to the region (http://uvg.edu.gt; https://www.youtube.com/ watch? $\mathrm{v}=\mathrm{xo} 21 \mathrm{sDK}$ tiw4). Lastly, UVG obtained the first place in the QS 2019 ranking for Guatemala and the private universities in Central America.

2. UVG was the first university in Latin America to install a Psi Chi Chapter, in the year 2012 after two years of preparation. For the past six years there have been four different inductions, accounting for more than 40 Psi Chi members (Figure 7).

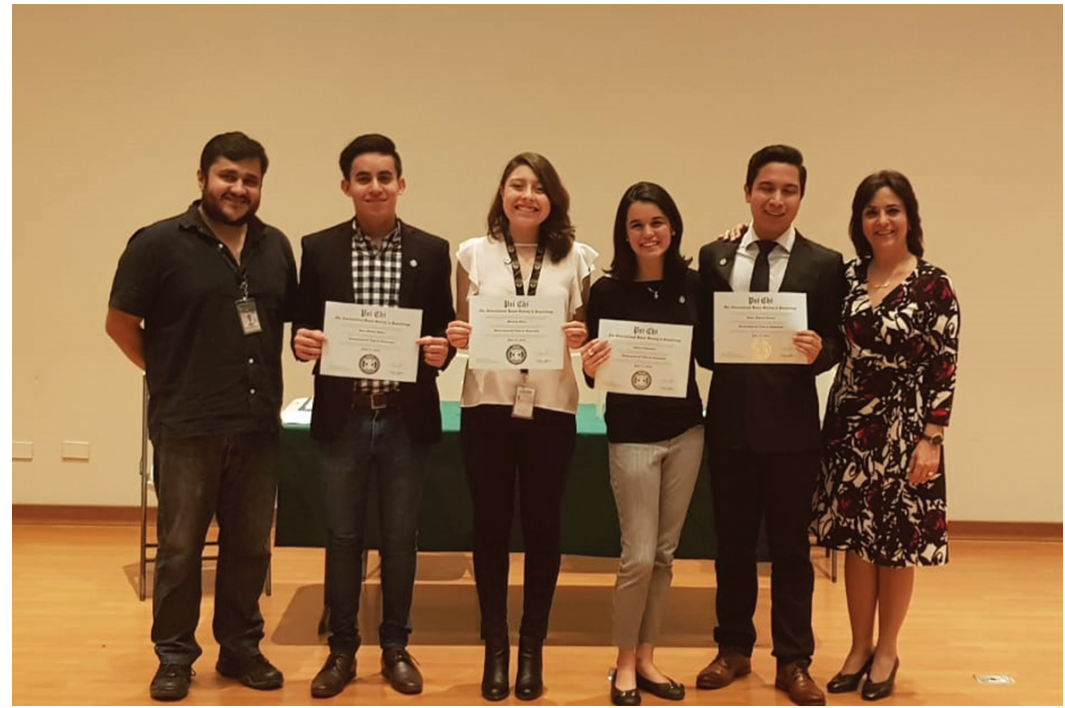

Figure 7. 5th Anniversary of the Latest Psi Chi Chapter in Guatemala on July 20, 2018 
3. Founding Chapter Faculty Advisor was Professor María del Pilar Grazioso and first President was Wendy Acevedo who led the development of the Chapter helped by UVG graduates Meri Lubina and María Andrée Maegli. Dr. Grazioso continues to be the Faculty Advisor and current President is Marvin Chávez.

4. Throughout these years the Guatemalan Chapter has been active in engaging in international collaboration with Psi Chi board as well as with other Chapters in the US and Russia. In addition, it has served to disseminate information to other countries in Latin America so that other Chapters can begin.

During all these years, Psi Chi has committed to several areas:

- expanding healing processes with people involved in disasters (Figure 8);

- community volunteer activities;

— promoting suicide prevention;

- academically, a psychological newsletter was created with the purpose of educating the faculty and students about mental health issues;

- creating new therapy spaces as was the play therapy space in the community clinics (CIPA);

- submitting publications in the Eye on Psi Chi magazine;

- developing informative videos to disseminate in Spanish what Psi Chi is;

— attending congresses and presenting research material created by students.

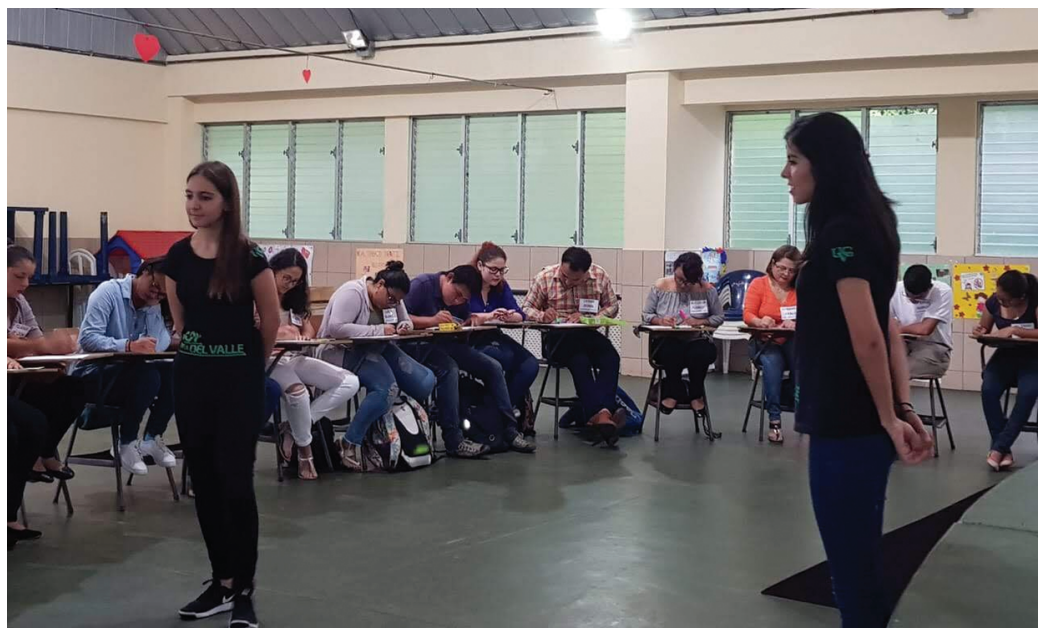

Figure 8. Psi Chi Chapter Staff Working with Those Affected by Natural Disasters

5. For the future, the Guatemalan Chapter is committed to increase and expand international collaborations with Central America, the Caribbean, and other university Chapters in other regions of the world. Expand the outreach and membership of the Chapter in Guatemala. Another plan is to participate in conferences and congresses not only as attendees but as professionals. Lastly, it is also a plan to earn grants to expand the field of Psychology in Guatemala.

6. UVG Chapter can host international encounters and facilitate the traveling exchange in our beautiful country. Guatemala can be a wonderful setting for international encounters due to the fact that it is rich in culture, flora and fauna that can enrich the experience. The chapter has the goal of doing this to move forward towards obtaining funding. 


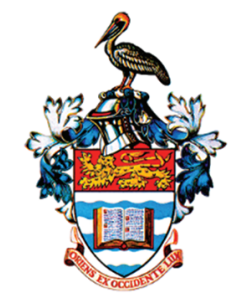

\section{Psi Chi at The University of the West Indies, St. Augustine Campus, Trinidad and Tobago}

(by Diana Williams, Grace Sooknanan \& Alicia Hosein)

1. The University of the West Indies (UWI), St. Augustine Campus is located in one of the Caribbean's most rapidly developing island states, Trinidad and Tobago, $15 \mathrm{~km}$ away from the capital. The campus was formed in 1960, twelve years after The UWI was first founded in Jamaica. Together with its sister campuses (i.e., Cave Hill, Mona and the Open Campus), The UWI St. Augustine serves 17 countries of the Commonwealth Caribbean, has faculty and students from more than 40 countries, and has collaborative links with over 160 universities globally. With its focus on research and innovation, fully accredited programmes across seven faculties, and a cosmopolitan campus community, The UWI St. Augustine is a true representation of an innovative, internationally competitive, contemporary university deeply rooted in the Caribbean.

2. On March $21^{\text {st }} 2013$, the ANSA McAL Psychological Research Centre ${ }^{1}$, in collaboration with the Department of Behavioural Sciences (DBS) ${ }^{2}$, hosted the Installation and Inaugural Induction Ceremony of the UWI St. Augustine Campus Psi Chi Chapter (Figure 9). A total of 40 undergraduate, postgraduate, and alumni members were inducted at this historic ceremony (https://sta.uwi.edu/uwitoday/archive/june_2013/article14. asp).

At the time, The UWI, St. Augustine was one of a select number of higher education institutions to have gained entry into the Society, not to mention the sole university to have done so within the Caribbean. The introduction of the Chapter to the campus was spurred largely by recognition of the continued growth of the discipline of Psychology at the campus, as well as The UWI's identification of internationalisation as a major objective in enhancing the university's reach and impact. The ANSA McAL Psychological Research Centre is extremely grateful to Professor Jason Young who as Psi Chi President encouraged the establishment of the St. Augustine Campus.

3. The founding Chapter Faculty Advisor, Co-Advisor, and President were Professor Derek Chadee, Head of the DBS, Dr. Jannel Phillip, faculty member of the Department's Psychology Unit, and Ms. Nikita Ng Ying, respectively. Professor Chadee has since maintained his role as Faculty Advisor, while Dr. Heather Hollingsworth, also a faculty member of the Psychology Unit, currently serves as the faculty Co-Advisor in place of Dr. Phillip.

1 The ANSA McAL Psychological Research Centre is a research unit at The UWI, St. Augustine, which has played a core role in the growth of Psychology at the University.

2 The Department of the Behavioural Sciences is a multidisciplinary department (housing the Psychology, Sociology, Social Work, Criminology, and Mediation Units) at The UWI, St. Augustine. 


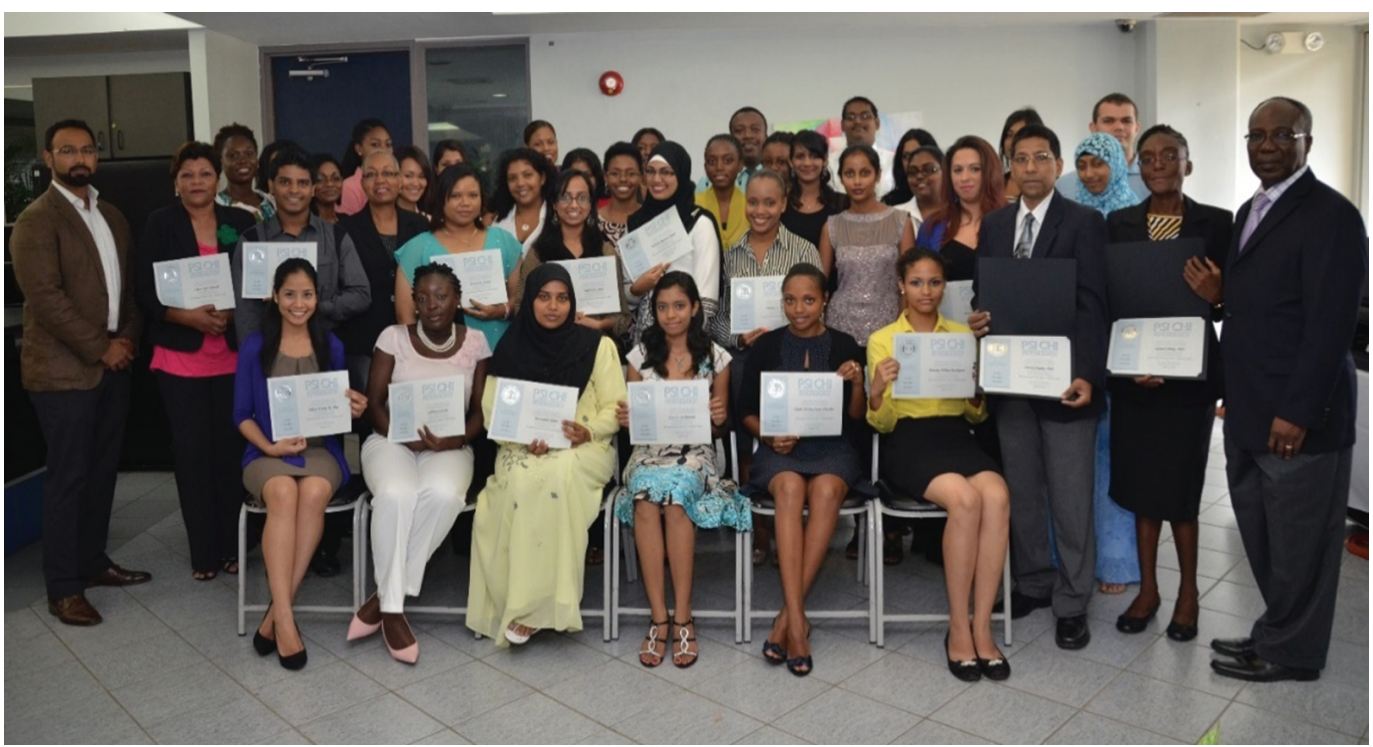

Figure 9. The UWI St. Augustine Campus Psi Chi Chapter Installation Ceremony

4. Since 2013, The UWI Chapter has developed five unique activities.

A. Annual Undergraduate Student Research Conference. Since its installation at The UWI, St. Augustine, the Chapter has continued to host its Annual Undergraduate Student Research Conference. The first of its kind, this event provides final year psychology students with the opportunity to showcase their research projects in front of peers and colleagues on-campus. It also provides students with experience presenting their work in a formal setting (https://sta.uwi.edu/news/releases/release.asp?id=1079; https://www. facebook.com/PsiChiUWI/).

B. Annual Induction Ceremony. As a formal result of its membership drives, The UWI St. Augustine Campus Psi Chi Chapter hosts annual ceremonies aimed at formally welcoming new members to the Chapter.

C. Student Seminars and Workshops. In effort to further the discipline of psychology on-campus, the Chapter has staged a number of workshops since its installation. The most notable of these is its Research Writing Workshop, held bi-annually to equip psychology students with tips on how to conduct their own research. This workshop has continued to have a significant impact over the years, particularly among final year students undertaking their research projects. Other seminars/workshops hosted thus far include: The Peer Support Workshop (2014), Applying Art Therapy to the Context of Trinidad and Tobago (2018).

D. Psych Fair. In 2014, the Chapter hosted a fair aimed at raising awareness of psychological theories and applications through fun games and examples. This event targeted the general student population and was a resounding success.

E. One Mic Night. This event, hosted in 2013 and 2014, offered students a forum for showcasing their talents. It was held with the intention of fostering networking and camaraderie among active and potential members.

5. Future possibilities. Cross-Cultural Virtual Conference. The hosting of a virtual conference for students, particularly those pursuing Psychology at the undergraduate 
level, could allow members of various Psi Chi Chapters to partake in activities undertaken by The UWI St. Augustine Chapter (e.g., student research conferences). This would create greater cohesion among the chapters. Establishment of a Research Committee. The introduction of a research committee within The UWI St. Augustine Campus Psi Chi Chapter could foster a culture of student research. This committee could increase students' understanding of the process, and raise awareness of opportunities (e.g., grants) offered by Psi Chi. Cross-Faculty Collaborations. Through collaboration between the chapter and other faculties, students within other disciplines can be provided with a general knowledge of psychological theories and how they may be useful/applicable in various fields. Collaboration with "World of Work". World of Work (WOW) is an initiative of The UWI aimed at providing final year students with the tools necessary for their successful transition to the work environment. This entails providing a forum for receiving advice from leading experts, practicing interviewing skills, and networking with local and international recruiters. Collaboration between the Chapter and WOW could allow for the promotion of students' awareness of careers in the field of psychology, and could provide information on the necessary steps to achieve desired career paths.

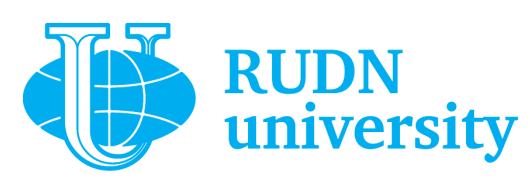

\section{Psi Chi at the Peoples' Friendship University of Russia (RUDN University), Russia \\ (by Harold Takooshian, Ph.D., Valeriia S. Tarkhova, Sayad Z. Kardashova \& Yulia V. Kozhukhova)}

1. The Peoples' Friendship University of Russia (RUDN University) is located in central Moscow (http://eng.rudn.ru/about). The RUDN University campus is situated in southwestern Moscow in one of the beautiful and ecologically clean places of the city. The most "green" Russian university (according to the UIGreenMetric World University Ranking, 2017) is located nearby the parkland covered 50 hectares (http://eng.rudn.ru/ about/our-campus/). RUDN University was formed in 1960 as a multicultural urban university, now with 30454 students, coming from 155 countries. It is the most international university in Russia because the proportion of international students is $30 \%$. The annual QS survey ranks RUDN University as \#446 among the world's universities (www. topuniversities.com/universities/rudn-university). Mission of RUDN University says: "Uniting people of different cultures by knowledge RUDN University creates leaders to make the World better" and one of RUDN University core values is multinationality and international cooperation (http://eng.rudn.ru/about).

RUDN University also publishes a peer-reviewed Journal of Psychology and Pedagogics (http://journals.rudn.ru/psychology-pedagogics/index), which includes articles on Psi Chi (McCormick et al., 2014; Novikova et al., 2019; Takooshian et al., 2014, etc.).

2. RUDN University was the first school in Russia to install its Psi Chi Chapter (Figure 10), on 11 October 2013 - a joyous gathering of over 120 students and faculty (www.youtube.com/watch? $v=$ ggtdPVAPjJY). The 1000 schools in Russia today include 
many outstanding schools, but RUDN University stands out in its close faculty — student rapport, which encouraged Professors Elena Chebotareva and Irina Novikova to successfully petition for a Psi Chi Chapter (Takooshian et al., 2014).

3. Founding Chapter Faculty Advisor was Professor Elena Chebotareva and first President was Valeria Tarkhova. Since 2018, Chapter Faculty Advisor is Professor Irina Novikova and President is Elina Kaminskaya.

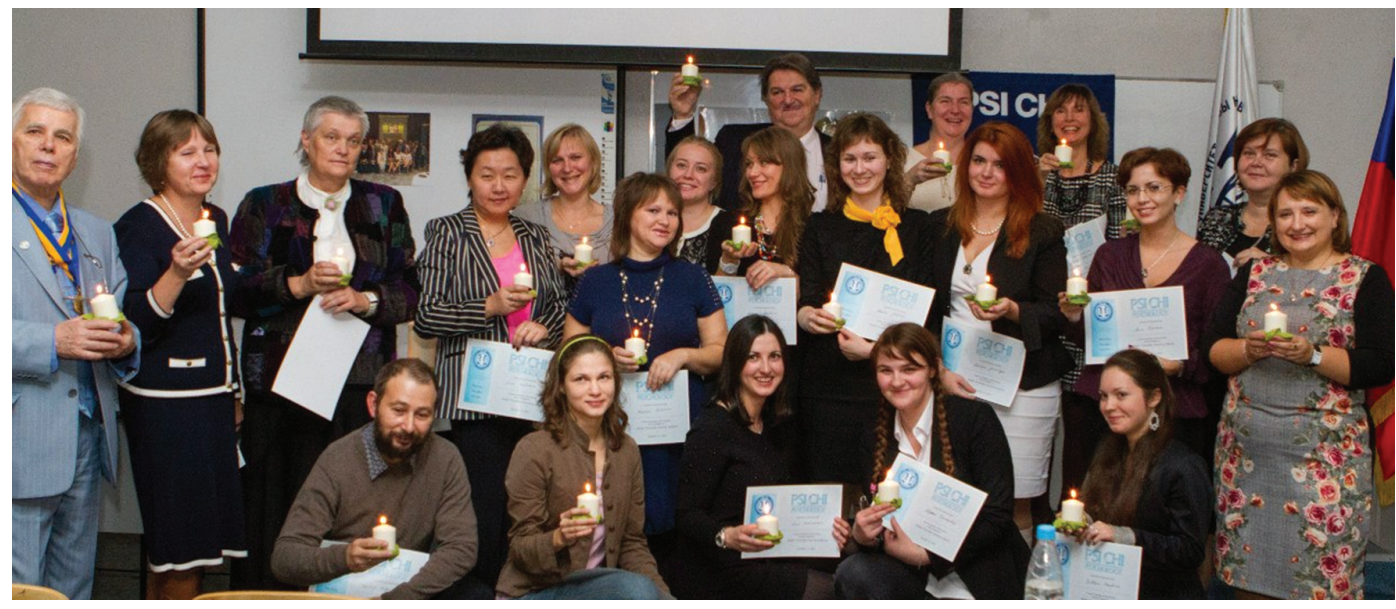

Figure 10. Installation of the RUDN University Psi Chi Chapter in Moscow during Science Week with the Participation of Professor Harold Takooshian, on 11 October 2013

4. In the fall of 2018 Psi Chi Chapter at RUDN University had 5th anniversary (Novikova et al., 2019). Since 2013, Psi Chi at RUDN University has flourished in at least 4 ways.

A. It is an organization of the student scientific conferences in which hundreds of students of RUDN University and other Russian universities have the opportunity to participate, to present and publish the results of their research: on $27^{\text {th }}$ of October 2013, the Moscow Psi Chi Conference gathered 40 teachers and students from different universities; from 2013-2018, the Annual Young Psychologists Conference organized by the Social and Differential Psychology Department of the RUDN University and the Psi Chi Chapter of University; on 30 October 2015, a Teleconference with the UN Psychological Coalition in New York City.

B. It is an organization of the international competitions of students' research projects: the International Competition of Research Projects for Young Scientists on "Psychological Well-Being in Modern Society", 3 winners from RUDN University (October - November 2015); Petrovic Awards for the best multicultural research from Fordham University (USA), 4 winners from People's Friendship University of Russia (November 2015); RUDN University students joined two Psi Chi international students' research projects on "Wealth and Happiness Across the World" and "Life Values Cross-Cultural" (20152016); annual competition of student reports at Young Psychologists Conferences at RUDN University (2013-2018).

C. Support of student participation in international scientific conferences, meetings, and congresses in Russia and abroad: annual meetings of the EPA, APA, and APS (USA, 2013-2016); annual conferences of psychologists and educators organized by the Social 
and Differential Psychology Department at the RUDN University, young psychologists symposium (RUDN University, 2013-2019); the first APS regional teaching workshop in Russia on "Improving the Psychology Teaching Techniques" (Higher School of Economics, 2015).

D. Support for the scientific and professional development of students. For the example, since 2013, two RUDN University Psi Chi Chapter members received a PhD in Psychology, eight - a MA in Psychology, ten - BA in Psychology. Five students became teachers of psychology, five - counseling psychologists.

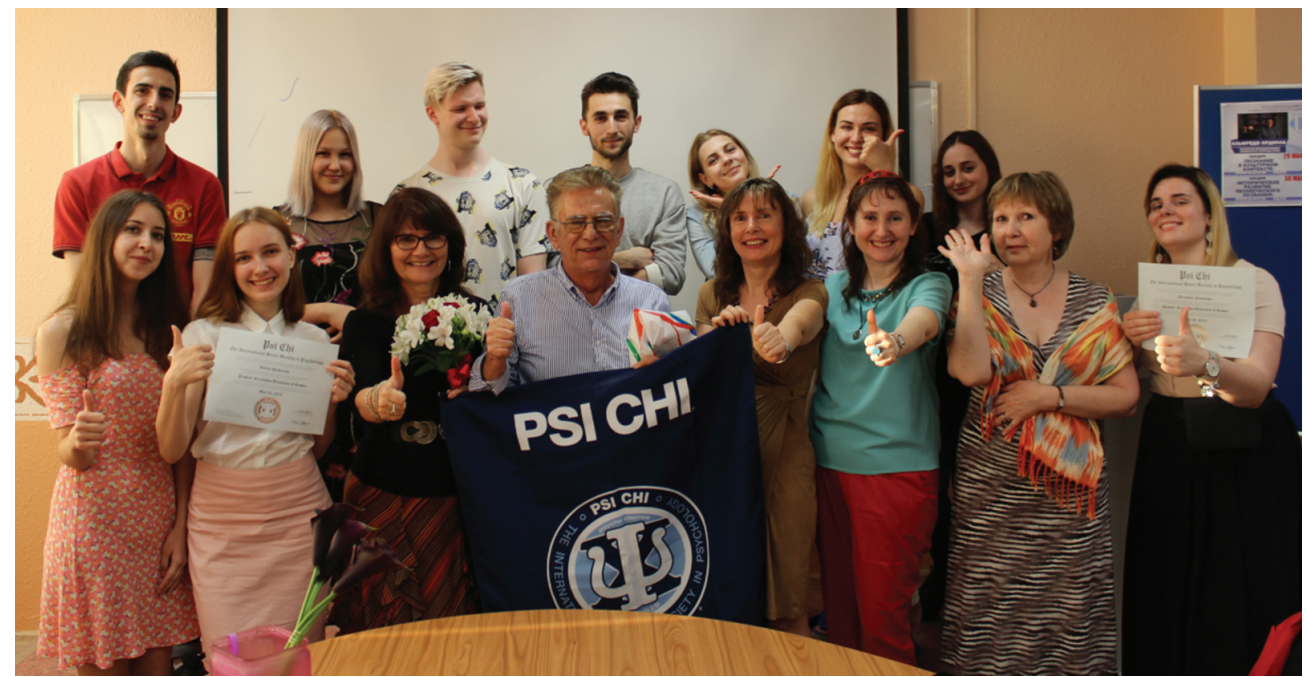

Figure 11. Induction Ceremony at the RUDN University Psi Chi Chapter with the Participation of U.S. Professors Alfredo Ardila and Monica Rosselli, on 30 May 2019

5. A possible prospect for the development of Psi Chi Chapter at RUDN University may be international cooperation with other universities (Figure 11), Psi Chi Chapters, as well as international student exchange.

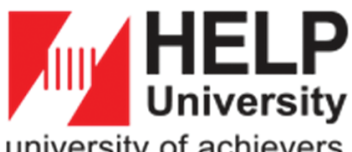

university of achievers

\section{Psi Chi at HELP University, Malaysia}

(by Tsee Leng Choy, Ph.D.)

1. Established in 1986, HELP University spans three campuses in Kuala Lumpur, catering to 8000 students (including 2100 international students) and 570 staff. Having pioneered psychology in Malaysia in 1999, HELP houses one of the most established and the largest undergraduate Psychology program in Asia (1300 full time students) (https://www.help.edu.my/).

2. Having an established regional and national reputation in psychology, HELP University was the first Asian and Malaysian university to install a Psi Chi Chapter on 26 August 2015. To date, this Chapter has inducted more than 380 members (Figure 12). 


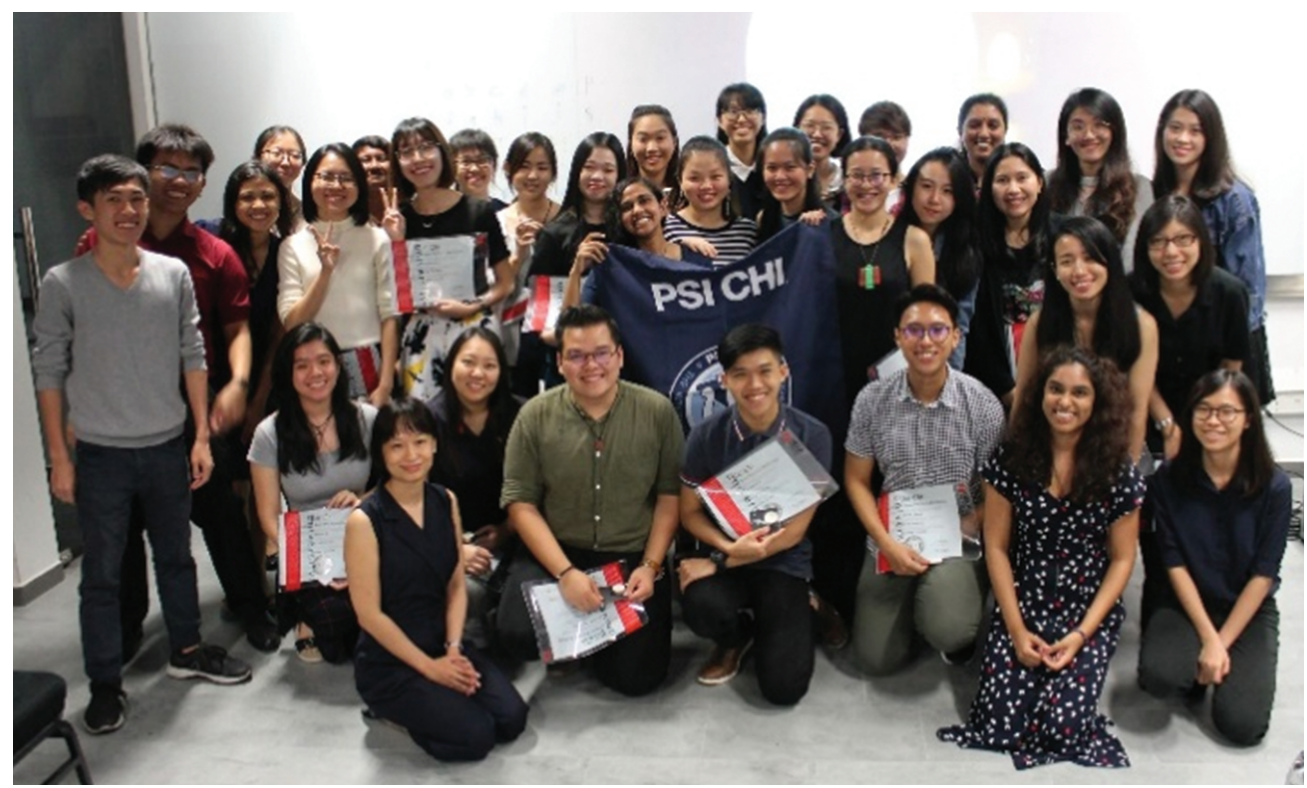

Figure 12. Induction Ceremony and Game Night (January 2019)

3. The founding Chapter Faculty Advisor was Dr. Cameron Teoh and the President was Catherine Foo. Since 2017, the Faculty Advisor is Dr. Tsee Leng Choy and the Presidents have been Ong Ray Gan (2016-2017), Andrea Chew (2017-2018) and Anne Sharmila Selvam (2018-2019).

4. Since 2015, the Chapter has (https://campayn.com/contact_list_form/ signup/80506?; https://www.facebook.com/HELPUniversityPsiChi/ ):

A. Organized workshops to educate the students on psychology and global issues. These have ranged from APA formatting, psychological first aid and sexual harassment (Figure 13).

B. Planned retreats for team bonding. These popular annual retreats for networking are open to members and non-members alike, including lecturers, alumni and students.

C. Implemented tutoring initiatives. Since 2016, select members with strong academic grades have served as peer tutors with the Department of Psychology.

D. Formed sharing groups, game sessions and mini competitions for recruitment and bonding. This has progressed from posting discussion threads on Youtube and online platforms (emotion, sleep, suicide, depression) to self-organized sessions (i.e. the depression support group named "You Matter"). Debates, quiz challenges and board game sessions are also routine.

E. Planned a proposal to combat sexual harassment on campus and educated the students on proactive measures. In 2019, this initiative to raise awareness and propose a better operating procedure for sexual harassment cases within campus included Think Tank sessions, opinion boxes, education booths, talks and a self-defence class in collaboration with the Taekwondo Club and AWAM.

5. A future possibility for the HELP Chapter would be to participate in international Psi Chi conferences and to increase networking among the various Psi Chi Chapters (e.g. online networking). 


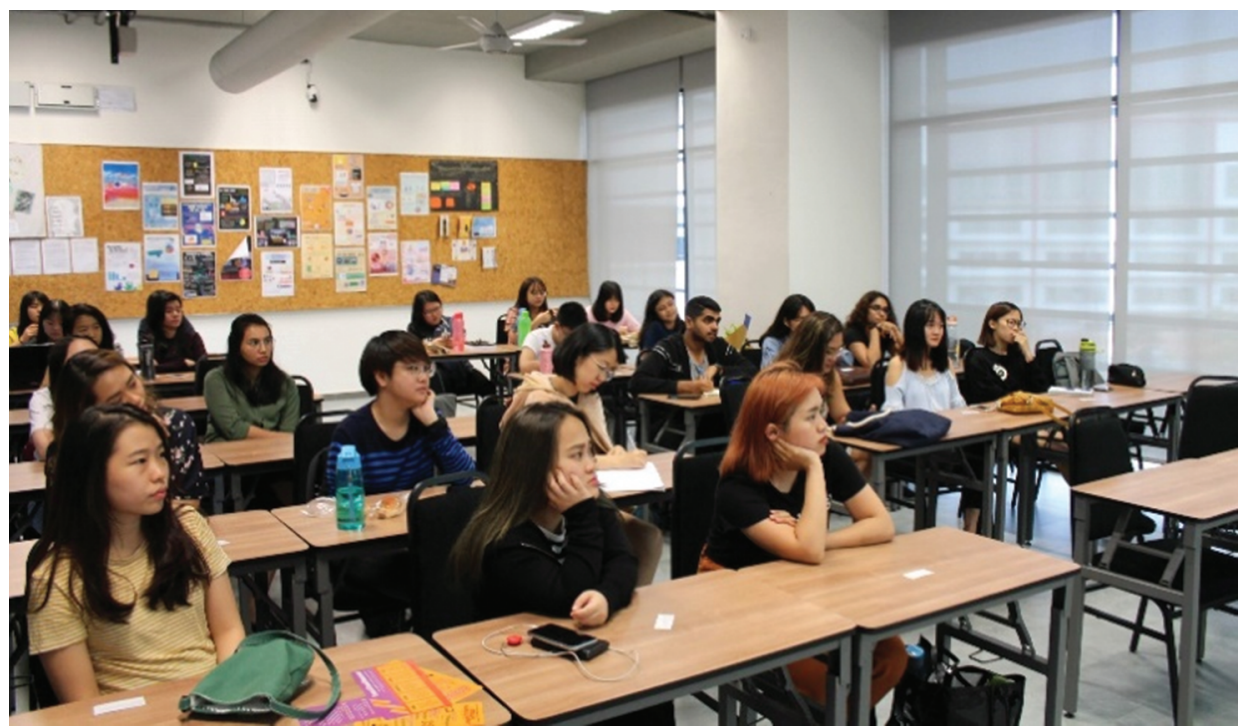

Figure 13. Sexual Harassment Awareness Talk (February 2019)

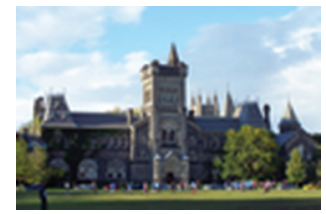

\section{Psi Chi at University of Toronto Scarborough, Canada}

(by Kyle Danielson, Ph.D.)

1. The University of Toronto Scarborough (UTSC) is one of the University of Toronto's three campuses, located in Ontario, Canada (https://en.wikipedia.org/wiki/University of_Toronto_Scarborough). Founded in 1827, the University of Toronto is the top-ranked university in Canada, and the UTSC campus hosts over 13000 students (https://www. topuniversities.com/universities/university-toronto).

2. UTSC's Psi Chi Chapter is the fifth in Canada and was launched in the Fall of 2017 (https://www.utsc.utoronto.ca/projects/psichi/about-content/). We had our first induction ceremony in March of 2018, and currently have 115 active members in our Chapter. UTSC has a focus on excellence in undergraduate education and seemed a natural fit for a new Psi Chi Chapter. So far, UTSC student Olivia Rennie (BSc, 2018) received a Psi Chi Undergraduate Research Grant for her research using a light-based method to examine the role of the ventral hippocampus in approach-avoidance behaviour (https://utsc.utoronto.ca/news-events/undergraduate-experience/where-does-anxietycome-u-t-student-research-focuses-understanding-mental).

3. The Chapter was founded by Professor Michael Souza and the inaugural President was Kristen Albano. Since 2017, Professor Kyle Danielson is the Chapter Faculty Advisor. This is very new Chapter is just over one year old, and looks forward to expanding in coming years (Figure 14). 


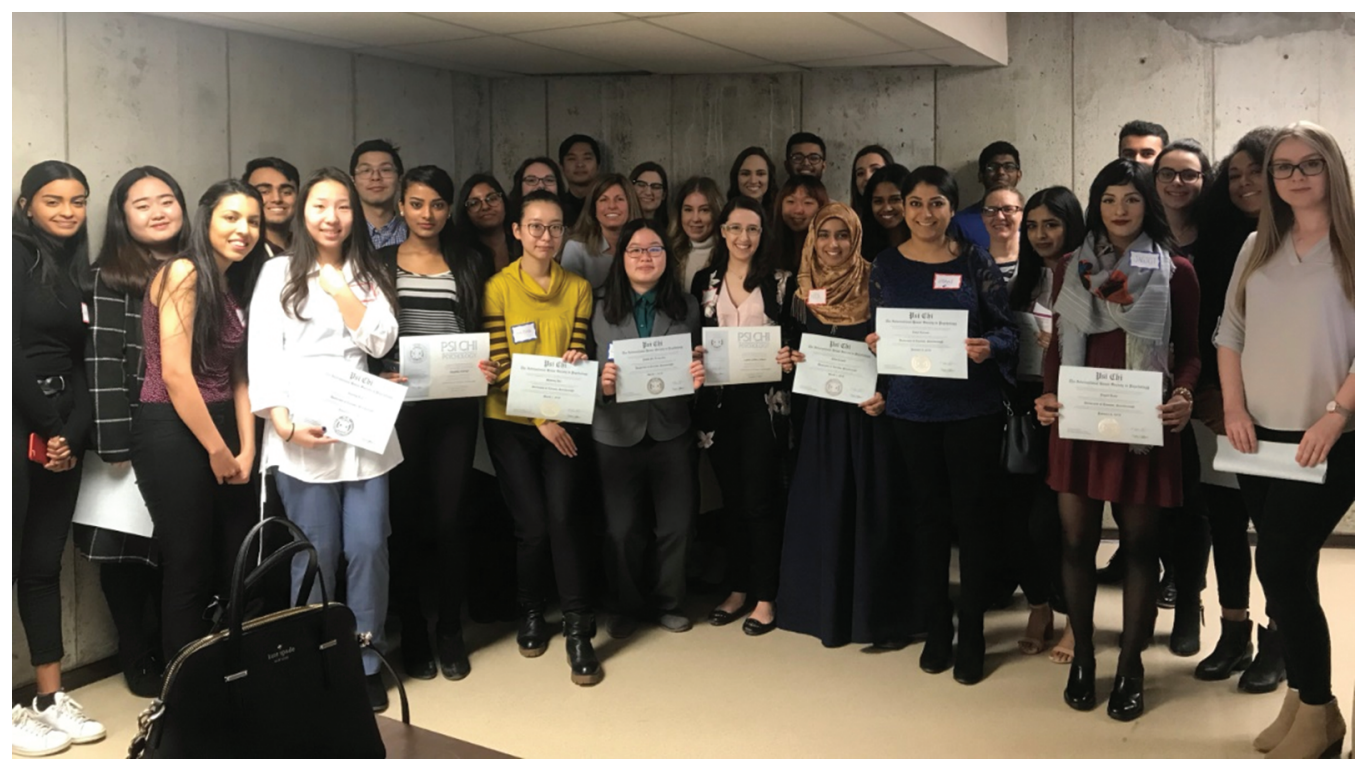

Figure 14. Inaugural Induction Ceremony for the University of Toronto Scarborough's Psi Chi Chapter in March of 2018

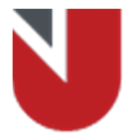

\section{UNIVERSITY of NICOSIA}

\section{Psi Chi at University of Nicosia, Cyprus}

(by Marios Adonis, Ph.D., Yianna Ioannou, Ph.D. \& Ester Lima)

1. The University of Nicosia (UNIC) is located in Nicosia, the capital of Cyprus (https://www.unic.ac.cy/dynamic-urban-campus/the-city-of-nicosia/). UNIC is the largest university in Cyprus, with more than 11500 students, coming from over 70 different countries. The annual QS survey ranks UNIC as \#91 between the top universities of the Emerging Europe and Central Asia Region (EECA) (https://www.unic.ac.cy/unicranked-among-top-100-universities-in-the-eeca-region/). UNIC's mission is: "To promote research and the generation of knowledge; to be of service to society through the dissemination and application of knowledge, as well as through innovative partnerships with business and civic society institutions". A core value of UNIC is integrity in a personal and academic level (https://www.unic.ac.cy/unic-at-a-glance/the-universitys-mission/).

2. UNIC was the first University in Cyprus to install its Psi Chi Chapter, on 31 January 2018 - a remarkable ceremony that gathered faculty members and students (Figure 15). The University of Nicosia through its committed faculty members has achieved great academic advancements, and the initiative of Proffessor Charles Spirrison and Dr. Marios Adonis to bring the distinctive honor society, Psi Chi to the university illustrates it.

3. Founding Chapter Faculty Advisor was Dr. Marios Adonis and first President was Andrea Evdokimou. Chapter Faculty Advisors are Dr. Yianna Ioannou and Dr. Maria Hadjimarkou. Since September of 2018 President is Ester Lima. 


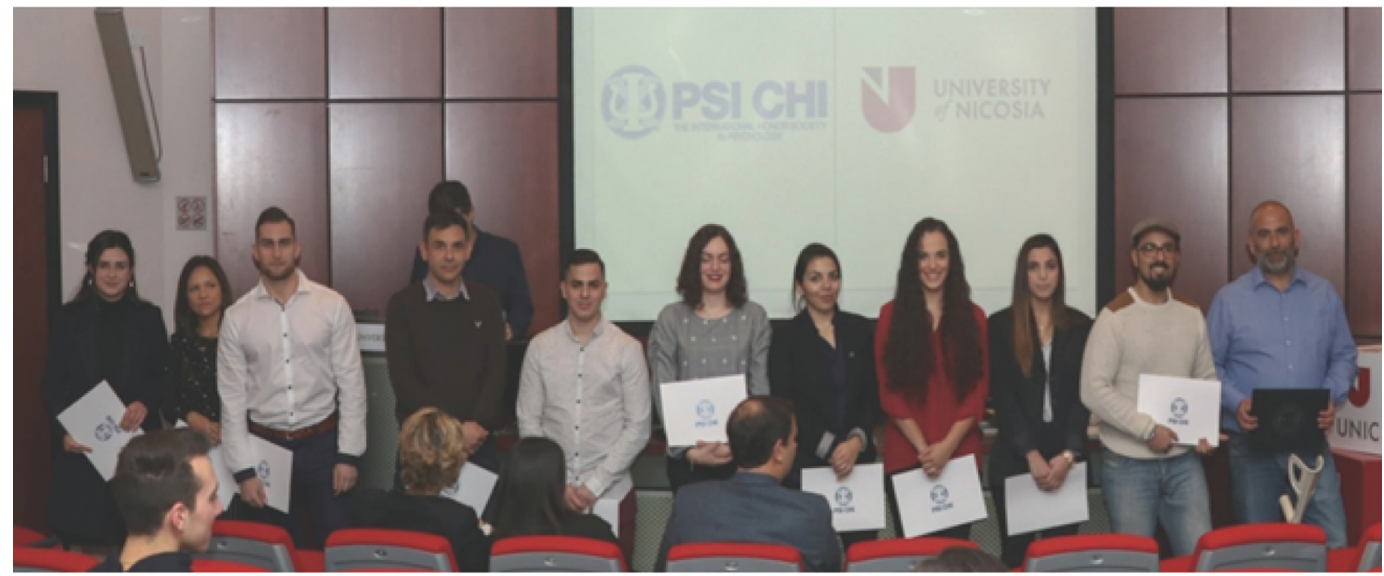

Figure 15. UNIC Installs its Psi Chi Chapter in Cyprus on January 31, 2018

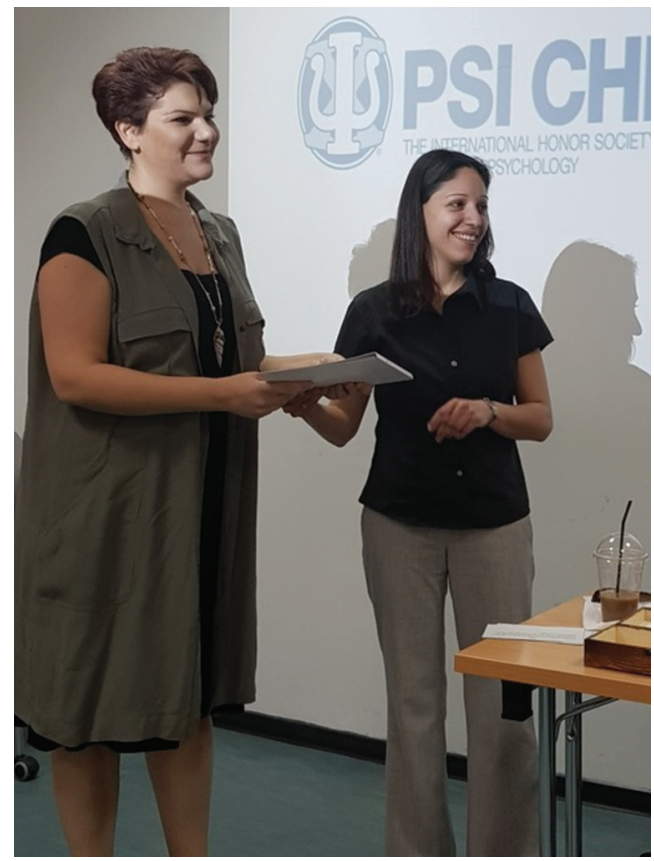

Figure 16. Ms. Katerina Georgaki (Director of UNIC Mentor Programme) with Dr. Yianna loannou (Advisor of UNIC Psi Chi Chapter) Formalizing the Partnership between Mentor Programme and Psi Chi

4. Psi Chi Chapter at UNIC had just completed its first anniversary on January of 2019. Even though the Chapter is new we have already almost double the number of members and partnered with the psychology society of the university in their Christmas toy collection, and with the UNIC mentor program that provides assistance to primary school students (Figure 16).

5. For the future, Psi Chi Chapter at UNIC is looking forward to develop research projects with its members, and to foster the team spirit between its members through the development of social initiatives that benefit the society. 


\section{Wishes to Psi Chi \\ (anonymous, in a random order)}

As a wish, we would like Psi Chi:

- to create or fine-tune a structure that could serve better to link all international chapters, including ways to report international chapters' activities. This in turn could potentially maximize networking at regional conferences, or facilitate outreach to other universities that currently do not have a Psi Chi chapter;

- to consider improving and developing new avenues for the exchange of experiences and knowledge between chapters;

- more activities such as conferences outside the USA for better access to international chapters;

- to consider introducing alternative requirements for membership entry other than the Cumulative Grade Point Average Grade, and exploring means to deal with extremely passive members who do not contribute (e.g. merit point based system). This may also aid in determining the allocation of grants and scholarships;

- to increase support for cross-chapter collaboration. The provision of support, particularly through funding, for cross-chapter activities (e.g., student exchanges, conferences, etc.) could strengthen relationships among chapters;

- to increase accessibility of research grants. Extending grant opportunities to alumni members, rather than solely active members, could prove beneficial;

- to create a structure to better link its international chapters, so these can better network at regional conferences, or outreach to local schools with no Psi Chi chapter;

- to establish travel grant for international members so they can visit Psi Chi activities at the USA.

In conclusion, we would like to wish the Psi Chi further development and improvement of the knowledge and experience exchange between all chapters!

\section{References}

McCormick, M.A., Takooshian, H., Denmark, F.L., del Pilar Grazioso, M., Velayo, R.S., Wang, A.Y., \& Zlokovich, M.S. (2014). Building Bridges: Psi Chi and International Psychology. RUDN Journal of Psychology and Pedagogics, (4), 5-16. http://dx.doi.org/10.22363/2313-1683-2014-4-5-16

Novikova, I.A., Tarkhova, V.S., Kardashova, S.Z., \& Kharitonenko, A.A. (2019). First and Only Russian Psi Chi Chapter: 5 years at the RUDN University! RUDN Journal of Psychology and Pedagogics, 16(1), 101-109. http://dx.doi.org/10.22363/2313-1683-2019-16-1-101-109

Takooshian, H., Novikova, I.A., \& Chebotareva, E.Y. (2014). Psi Chi at PFUR: First Russian Chapter of the International Honor Society in Psychology. RUDN Journal of Psychology and Pedagogics, (1), 118-123. (In Russ.)

\section{Article history:}

Received: 20 April 2019

Revised: 15 May 2019

Accepted: 30 May 2019

\section{For citation:}

Takooshian, H., Nieves-Lebrón, Ya., Delgado-Acosta, B.M., Talavera Pagán, D., CruzBermúdez, N.D., Rivers, A.M., del Pilar Grazioso, M., Mejía, M., Williams, D., Sooknanan, G., 
Hosein, A., Tarkhova, V.S., Kardashova, S.Z., Kozhukhova, Yu.V., Tsee Leng Choy, Danielson, K., Adonis, M., Ioannou, Y., Lima, E. (2019). Psi Chi in Global World: Vision of 9 International Chapters. RUDN Journal of Psychology and Pedagogics, 16(2), 245-269. http://dx.doi. org/10.22363/2313-1683-2019-16-2-245-269

\section{Bio Notes:}

Harold Takooshian, Ph.D., is Professor of Psychology, Urban Studies, and Organizational Leadership at Fordham University (USA, New York). He is Past-President of the APA Division of International Psychology (2003), and Past Officer and President of Psi Chi from 1993-2000. He was elected a Distinguished Member of Psi Beta and Psi Chi. Like thousands of others, he is deeply grateful to Psi Chi for its many impacts on his life. E-mail: takoosh@aol.com

Yarielizmar Nieves-Lebrón, a 5th-year undergraduate student of the Psychology Department of the University of Puerto Rico, Mayaguez Campus (Mayaguez, Puerto Rico). Psi Chi member since 2017. Historian of Psi Chi Chapter UPRM since 2018. E-mail: yarielizmar.nieves@upr.edu

Bernadette Delgado-Acosta, Ph.D. School Psychology, Texas A\&M University (1995); M.S. School Psychology, Texas A\&M University (1993). Professor at the University of Puerto Rico, Mayaguez Campus (Mayaguez, Puerto Rico). The Faculty Advisor of Psi Chi Chapter UPRM since 2008 to the present. E-mail: bernadette.delgado@upr.edu

Daniela Talavera Pagán, senior psychology undergraduate student and President of the Psi Chi Chapter at the University of Puerto Rico, Río Piedras Campus (Río Piedras, Puerto Rico). E-mail: daniela.talavera@upr.edu

Nelson D. Cruz-Bermúdez, Ph.D. in Neuroscience, Professor of Psychology and Mentor of the Psi Chi Chapter at the University of Puerto Rico, Río Piedras Campus (Río Piedras, Puerto Rico). E-mail: nelson.cruz6@upr.edu

Andrew M. Rivers, Ph.D. in Psychology, Lecturer, Department of Psychology, University of British Columbia (Vancouver, Canada). Faculty Advisor of the Psi Chi Chapter at UBC. E-mail: amrivers@ psych.ubc.ca

Maria del Pilar Grazioso, Ph.D. in Psychology, Professor of Psychology and Faculty Advisor of the IV Psi Chi Chapter at the University of the Valley of Guatemala since 2012 (Guatemala, Guatemala). E-mail: mpgrazioso@gmail.com

Marinés Mejía, psychology undergraduate student and Secretary of the IV Psi Chi Chapter at the University of the Valley of Guatemala (Guatemala, Guatemala). E-mail: mej15198@uvg.edu.gt

Diana Williams, postgraduate student in Psychology at the Department of Behavioural Sciences of The University of the West Indies (UWI), St. Augustine Campus (Trinidad and Tobago, West Indies). Psi Chi member since 2018. Treasurer of the UWI St. Augustine Chapter since 2018. E-mail: diana.williams@sta.uwi.edu

Grace Sooknanan, B.Sc. Psychology (Hons.), M.Sc. Clinical Psychology (Distinction). Research Assistant for the INTREPID II project under the Psychiatry Unit of The University of the West Indies (UWI), St. Augustine Campus (Trinidad and Tobago, West Indies). One of the initial Psi Chi members inducted in 2013. Past President of the UWI St. Augustine Chapter 2017 to 2018. E-mail: grace_sooknanan@hotmail.com

Alicia Hosein, B.Sc. in Psychology, Research Assistant at ANSA McAL Psychological Research Centre, Department of Behavioural Sciences, Faculty of Social Sciences, University of the West Indies (UWI), St. Augustine Campus (Trinidad and Tobago, West Indies). Psi Chi member since 2018. E-mail: aliciafhosein@gmail.com 
Valeriia S. Tarkhova, Master of Psychology, Lecturer at Department of Psychology, Faculty of Social Sciences, Higher School of Economics (Moscow, Russia). Psi Chi member since 2013. First President of the Psi Chi Chapter at RUDN University (2013-2018). E-mail: valeria.tarhova@ gmail.com

Sayad Z. Kardashova, 4th year undergraduate student of the Social and Differential Psychology Department of Peoples' Friendship University of Russia (Moscow, Russia). Psi Chi member since 2017. Secretary of the Psi Chi Chapter at RUDN University since 2018. E-mail: sayadkardashova@ gmail.com

Yulia V. Kozhukhova, Assistant Professor of the Chair of Foreign Languages of the Faculty of Physics, Mathematics and Natural Science of the Peoples' Friendship University of Russia (Moscow, Russia). E-mail: kozhukhova_yuv@pfur.ru

Tsee Leng Choy, Ph.D., is Professor of Psychology and Faculty Advisor of the Psi Chi Chapter at the HELP University since 2017 (Kuala Lumpur, Malaysia). E-mail: choy.t1@help.edu.my

Kyle Danielson, Ph.D. in Psychology, Assistant Professor, Teaching Stream in the Department of Psychology, University of Toronto (Toronto, Canada). Faculty Advisor, The University of British Columbia Psi Chi Chapter 2016-2017; University of Toronto Scarborough Psi Chi Chapter 2017 _ present. E-mail: k.danielson@utoronto.ca

Marios N. Adonis, Ph.D. in Clinical Health Psychology. Associated Professor of Clinical Psychology and Department Chair at the University of Nicosia (Nicosia, Cyprus). E-mail: adonis.m@unic. ac.cy

Yianna Ioannou, Ph.D. in Clinical Psychology, Lecturer of Clinical Psychology and Coordinator of the MSc Program in Clinical Psychology at the University of Nicosia (Nicosia, Cyprus). E-mail: Ioannou.yi@unic.ac.cy

Ester Lima, 4th year undergraduate student of Psychology at the Department of Social Sciences, University of Nicosia (Nicosia, Cyprus). Psi Chi member since 2018. President of the Psi Chi Chapter at the University of Nicosia. E-mail: ester.ralima@hotmail.com 


\title{
Psi Chi в глобальном мире: взгляд 9 международных отделений
}

\author{
Г. Такушьян ${ }^{1}$, Я. Ньевес-Леброн ${ }^{2}$, Б.М. Дельгадо-Акоста ${ }^{2}$, \\ Д. Талавера Паган ${ }^{3}$, Н.Д. Крус-Бермудес ${ }^{3}$, Э.М. Риверс ${ }^{4}$, \\ М. дель Пилар Грациозо ${ }^{5}$, М. Мехия ${ }^{5}$, Д. Уильямс ${ }^{6}$, Г. Сукнанан ${ }^{6}$, \\ А. Хосейн ${ }^{6}$, В.С. Тархова ${ }^{7}$, С.3. Кардашова ${ }^{8}$, Ю.В. Кожухова ${ }^{8}$, \\ Ци Ленг Чой ${ }^{9}$, К. Дениэлсон ${ }^{10}$, М. Адонис ${ }^{11}$, \\ Я. Иоанну ${ }^{11}$, Э. Лима ${ }^{11}$ \\ ${ }^{1}$ Университет Фордхэм \\ Соединенные Штаты Америки, 10023, Нью-Йорк, 113 W. 60th St. \\ ${ }^{2}$ Университет Пуэрто-Рико в Маягуэс \\ Пуэрто-Рико, 00681-9000, Маягуэс, РО Вох 9000 \\ ${ }^{3}$ Университет Пуэрто-Рико в Рио Пьедрас \\ Пуэрто-Рико, 00925, Сан-Хуан, 9 Ave. Universidad, Suite 901 \\ ${ }^{4}$ Университет Британской Колумбии \\ Канада, V6T 1Z4, Ванкувер, West Mall, 2136 \\ ${ }^{5}$ Университет Валье де Гватемала \\ Гватемала, 01015, Гватемала, зона 15, Виста Эрмоса III, 18 Аve., 11-95 \\ ${ }^{6}$ Университет Вест-Индии \\ Вест-Индия, Тринидад и Тобаго, Кампус Св. Августина \\ ${ }^{7}$ Национальный исследовательский университет «Высшая школа экономики» \\ Российская Федерация, 101000, Москва, Мясницкая ул., 20 \\ ${ }^{8}$ Российский университет дружбы народов \\ Российская Федерация, 117198, Москва, ул. Миклухо-Маклая, 6 \\ ${ }^{9}$ Университет HELP \\ Малайзия, 50490, Куала-Лумпур, Букит Дамансара, Jalan Sri Semantan 1, \\ Off Jalan Semantan \\ ${ }^{10}$ Университет Торонто в Скарборо \\ Канада, ON M1C 1A4, Торонто, Military Trail, 1265 \\ ${ }^{11}$ Университет Никосии \\ Kunp, CY-241, Никосия, Makedonitissas Ave., 46
}

C тех пор как в 2009 году Psi Chi стало Международным психологическим обществом почета, выдающиеся преподаватели и студенты из многих стран вступили в семью Psi Chi, которая в настоящее время насчитывает более 750000 человек, работающих и обучающихся в 1130 учебных заведениях на шести континентах. Меняет ли принадлежность к Psi Chi жизнь людей в глобальном мире, как это происходит в США, начиная с 1929 года? Впервые в этой статье пионеры Psi Chi из девяти международных отделений рассказывают о собственном опыте работы в организации.

Ключевые слова: Psi Chi; Международное психологическое общество почета; международная психология; иностранные студенты; межкультурное взаимодействие 


\section{История статьи:}

Поступила в редакцию: 20 апреля 2019

Принята к печати: 30 мая 2019

\section{Для цитирования:}

Takooshian H., Nieves-Lebrón Ya., Delgado-Acosta B.M., Talavera Pagán D., Cruz-Bermúdez N.D., Rivers A.M., del Pilar Grazioso M., Mejía M., Williams D., Sooknanan G., Hosein A., Tarkhova V.S., Kardashova S.Z., Kozhukhova Yu.V., Tsee Leng Choy, Danielson K., Adonis M., Ioannou Y., Lima E. Psi Chi in Global World: Vision of 9 International Chapters (Psi Chi в глобальном мире: взгляд 9 международных отделений) // Вестник Российского университета дружбы народов. Серия: Психология и педагогика. 2019. Т. 16. № 2. С. 245-269. http://dx.doi. org/10.22363/2313-1683-2019-16-2-245-269

\section{Сведения об авторах:}

Такушьян Гарольд, Ph.D., профессор психологии, урбанистики и организационного лидерства в Университете Фордхэм (США, Нью-Йорк). Был президентом отделения международной психологии Американской психологической ассоциации (2003 г.), а также офицером и президентом Psi Chi (1993-2000 гг.). Избран заслуженным членом Psi Beta и Psi Chi. Как и тысячи других, он глубоко благодарен Psi Chi за сильное влияние на его жизнь. E-mail: takoosh@aol.com

Ньевес-Леброн Яриелизмар, студентка 5-го курса департамента психологии Университета Пуэрто-Рико (Маягуэс, Пуэрто-Рико). Член Международного психологического общества почета Psi Chi c 2017 г. Историк отделения Psi Chi в Университете Пуэрто-Рико (Маягуэс) с 2018 г. E-mail: yarielizmar.nieves@upr.edu

Дельгадо-Акоста Бернадетт, Ph.D., профессор Университета Пуэрто-Рико (Маягуэс, Пуэрто-Рико). Получила степень магистра наук в области психологии обучения в 1993 г. и степень доктора наук в области психологии обучения в 1995 г. (Техасский университет A\&M). Советник отделения Psi Chi в Университете Пуэрто-Рико (Маягуэс) с 2008 г. E-mail: bernadette.delgado@upr.edu

Талавера Паган Даниэла, магистрант в области психологии и президент отделения Psi Chi в Университете Пуэрто-Рико, кампус в Рио-Пьедрас (Рио-Пьедрас, Пуэрто-Рико). E-mail: daniela.talavera@upr.edu

Крус-Бермудес Нельсон Д., Ph.D. в области нейронаук, профессор психологии и руководитель отделения Psi Chi в Университете Пуэрто-Рико, кампус в Рио-Пьедрас (Рио-Пьедрас, Пуэрто-Рико). E-mail: nelson.cruz@upr.edu

Риверс Эндрю M., Ph.D. в области психологии, преподаватель департамента психологии Университета Британской Колумбии (Ванкувер, Канада). Советник отделения Psi Chi в Университете Британской Колумбии. E-mail: amrivers@psych.ubc.ca

Дель Пилар Грациозо Мария, Ph.D. в области психологии, профессор психологии и советник IV отделения Psi Chi в Университете Валье де Гватемала с 2012 г. (Гватемала, Гватемала). E-mail: mpgrazioso@gmail.com

Мехия Маринес, студент направления «Психология» и секретарь IV отделения Psi Chi в Университете Валье де Гватемала (Гватемала, Гватемала). E-mail: mej15198@uvg.edu.gt

Уильямс Диана, аспирант в области психологии, департамент поведенческих наук, Университет Вест-Индии, Кампус Св. Августина (Тринадад и Тобаго, Вест-Индия). Член Международного психологического общества почета Psi Chi c 2018 г. Глава финансового 
отдела отделения Psi Chi в Университете Вест-Индии (Кампус Св. Августина) с 2018 г. E-mail: diana.williams@sta.uwi.edu

Сукнанан Грейс, бакалавр психологии, магистр клинической психологии. Научный сотрудник по проекту INTREPID II в отделении психиатрии Университета Вест-Индии, Кампус Св. Августина (Тринадад и Тобаго, Вест-Индия). Один из первых членов Международного психологического общества Psi Chi с 2013 г. Экс-президент отделения Psi Chi в Университете Вест-Индии (Кампус Св. Августина) (2017-2018).E-mail:grace_sooknanan@ hotmail.com

Хосейн Алисия, бакалавр психологии, научный сотрудник Центра психологических исследований ANSA McAL, департамент поведенческих наук, факультет социальных наук, Университет Вест-Индии, Кампус Св. Августина (Тринадад и Тобаго, Вест-Индия). Член Международного психологического общества почета Psi Chi c 2018 г. E-mail: aliciafhosein@ gmail.com

Тархова Валерия Сергеевна, магистр психологии, преподаватель департамента психологии факультета социальных наук Высшей школы экономики (Москва, Россия). Член Международного психологического общества почета Psi Chi c 2013 г. Первый Президент отделения Psi Chi в Российском университете дружбы народов (2013-2018). E-mail: valeria. tarhova@gmail.com

Кардашова Саяд Зауровна, студентка 4-го курса кафедры социальной и дифференциальной психологии Российского университета дружбы народов (РУДН) (Москва, Россия). Член Международного психологического общества почета Psi Chi c 2017 г. Секретарь отделения Psi Chi в РУДН с 2018 г. E-mail: sayadkardashova@gmail.com

Кожухова Юлия Владимировна, старший преподаватель кафедры иностранных языков факультета физико-математических и естественных наук Российского университета дружбы народов (Москва, Россия). E-mail: kozhukhova_yuv@pfur.ru

Ци Ленг Чой, Ph.D., профессор психологии и советник отделения Psi Chi в Университете HELP с 2017 г. (Куала-Лумпур, Малайзия). E-mail: choy.tl@help.edu.my

Дениэлсон Кайл, доктор психологических наук, доцент, преподаватель кафедры психологии Университета Торонто (Торонто, Канада). Экс-советник отделения Psi Chi в Университете Британской Колумбии (2016-2017). Советник отделения Psi Chi в Университете Торонто в Скарборо с 2017 г. E-mail: k.danielson@utoronto.ca

Адонис Мариос H., Ph.D. в области клинической психологии и психологии здоровья, доцент, заведующий кафедрой клинической психологии Университета Никосии (Никосия, Кипр). E-mail: adonis.@unic.ac.cy

Иоанну Янна, Ph.D. в области клинической психологии, преподаватель клинической психологии и координатор магистерской программы по клинической психологии Университета Никосии (Никосия, Кипр). E-mail: ioannou.yi@unic.ac.cy

Лима Эстер, студентка 4-го курса департамента социальных наук Университета Никосии (Никосия, Кипр). Член Международного психологического общества почета Psi Chi c 2018 г. Президент отделения Psi Chi в Университете Никосии с 2018 г. E-mail: ester.ralima@ hotmail.com 